\title{
Workplace Deviance Among Hotel Employees : An Exploratory Survey
}

\author{
FARIDAHWATI MOHD. SHAMSUDIN \\ Faculty of Human and Social Development \\ Universiti Utara Malavsia
}

\begin{abstract}
This exploratory study examined workplace deviance among hotel emplovees in Langkawi, Malaysia. Specifically, it attempted to provide empirical answers to two main research questions: (1) what are the types of workplace deviance employees exhibit at the workplace, and (2) what work-related factors account for the exhibition of those acts. In order to address these questions, data were collected from 308 hotel employees. The findings showed that workplace deviance exists in organisations and takes on a variety of forms. The results also depicted that workplace deviance is influenced by a number of work-related factors, such as pay; supervision, co-workers, and management practices. In addition, employee deviance was also significantly related to the way they were treated by hotel guests. The implications of the study s findings on practice and theory are discussed.
\end{abstract}

\begin{abstract}
ABSTRAK
Kajian penerokaan menyelidik perlakuan yang menyimpang di tempat kerja di kalangan pekerja-pekerja hotel di Langkawi, Malaysia. Khususnya, ia bertujuan untuk memberikan jawapan empirik kepada dua persoalan utama kajian: (1) apakah jenis perlakuan yang menyimpang yang ditunjukkan oleh pekerja di tempat kerja, dan (2) apakah faktor yang berkait dengan kerja yang dapat menjelaskan perlakuan tersebut. Untuk menjawab dua persoalan ini, data telah dikutip daripada 308 orang pekerja hotel. Hasil kajian menunjukkan wujud penyimpangan perlakuan di dalam organisasi dan ia terdiri daripada pelbagai jenis. Dapatan juga menunjukkan bahawa penyimpangan perlakuan di tempat kerja dipengaruhi oleh beberapa faktor yang berkait dengan kerja, seperti gaji, penyeliaan, rakan sekerja, dan amalan pengurusan. Di samping itu, perlakuan yang menyimpang yang dilakukan oleh pekerja juga berkait secara signifikan dengan cara tetamu hotel mendapatkan perkhidmatan mereka. Implikasi dapatan kajian terhadap praktis dan teori turut dibincangkan.
\end{abstract}

\section{INTRODUCTION}

A review of the literature of worker behaviour within organisations suggests the dominance of research on good behaviour but few have attempted to study the other side of behaviour, such as workplace deviance which is also part of the organisational life as noted by many (e.g. Ackroyd \& Thompson, 1999). This is unfortunate because it is argued that workers are not always law or norm-abiding citizens in the workplace, or that they are constantly dutiful in the course of accomplishing their work (Ackroyd \& Thompson, 1999). The literature on workplace deviance is beginning to develop with more researchers conducting studies on the forms and types of deviance that workers engage in, the structure and also processes involved in the exhibition of workplace deviance by adopting; various theoretical frameworks and analyses. The literature, however, also suggests 
that the bulk of these previous studies have been devoted to understanding deviance exhibited by blue-collar employees in the manufacturing and industrial shop floor. Very little attention has been given on studying service workers, especially those who deal directly with people outside organisations, such as customers, clients, guests and passengers. Leidner (1993) refers to these groups of people as "interactive service workers," following the social interaction that primarily characterises their job.

It is argued that the extension of the model on worker behaviour that is chiefly based on the behaviour of blue-collar employees is problematic to the service worker behaviour (McCammon \& Griffin, 200()), because service work entails a triangular relationship that is generally missing in the manufacturing sector. In the service sector, employees do not only need to report to the management, but they also have to provide efficient service to customers. In essence, service employees have to report to "two bosses" (Shamir, 1980), instead of one. In this triad relationship, conflicting interests between the management and the customers become more problematic for the interactive service workers. For example, workers have to comply with the demands and desires of the management that the service provided is in accordance with the rules and procedures. But on the other hand, customers often perceive that good service is provided when workers fulfil their needs even if this means that they may have to bend the rules. Under this kind of relationship, it is obvious that workers are at a disadvantage in terms of their power status vis-à-vis management and customers. It has been proven from literature that despite being powerless, employees are still able to resort to a number of ways to deal and cope with this kind of difficult working conditions and one of which is by engaging in acts of deviance.

It should also be noted that despite the development of literature on employee deviance at work. studies in this are mostly conducted in the West. As workers' behaviours are to a certain extent shaped by the wider social context, studies should be conducted to ascertain whether Malaysian and Western workers' experiences at work are any different from one another. In Malaysia, a number of Malaysian scholars have attempted to examine how employees responded to various work controls within a capitalist discipline. Since they were not specifically interested in understanding deviance per se, this area was not given much emphasis. Furthermore, these studies were carried out among manufacturing employees (Halim, 1983, Levidow, 1991 \& Ong, 1987).

Due to the research issues raised above. this study was exploratory in nature, seeking to examine workplace deviance among hotel employees in Malaysia. Specifically. it aimed to address two main research questions: (1) what are the types and forms of workplace deviance Malaysian hotel employees engage in, and (2) what factors are related to the exhibition of deviance at the workplace. In this study, workplace deviance was defined as voluntary behaviour of organisational members that violates significant organisational norms and, in doing so, threatens the well-being of the organisation and/or its members (Robinson \& Bennett, 1995).

\section{LITERATURE REVIEW}

The literature identifies a number of different terms used by various scholars to refer to the concept of workplace deviance. Workplace deviance is sometimes referred to as "organisational misbehaviour" (Ackoryd \& Thompson, 1999; Vardi \& Wiener, 1996), "antisocial behaviour" (Giacalone \& Greenberg, 1997), and "dysfunctional behaviour" (Griffin, O'Leary-Kelly, \& Collins, 1998), to name a few. However, despite the use of different terms to refer to a similar behavioural domain, they share a similar conceptualisation. The above scholars generally claimed that workplace deviance is a negative organisational phenomenon, which can bring about adverse effects to the organisation and its members if not managed or controlled.

As workplace deviance encompasses a variety of different acts, scholars have developed a number of different typologies to facilitate theoretical understanding of the concept. One of the relevant typologies has been developed by Robinson \& Bennett (1995). They assert that 
workplace deviance can be categorised into four different clusters, based on two main dimensionsminor / serious, and organisationally / interpersonally directed. The former reflects the degree of harm resulted from the violation of the norms, and the latter reflects the target of the action, whether it is directed at the organisation or whether it is directed at other individuals in the organisation. Based on these dimensions, four clusters or families of deviant behaviour emerge, which they refer to as the 4P's of deviance. They are: (1) production deviance (minororganisational), which refers to behaviours which violate the formally proscribed norms delineating the quality and quantity of work to be accomplished. Included in this category are behaviours such as leaving early, taking excessive breaks, intentionally working slowly, and wasting resources; (2) property deviance (seriousorganisational), which refers to those instances where employees acquire or damage the tangible property or assets of the organisation without authorisation. Among deviant behaviours included in this category are activities such as sabotaging equipment, accepting kickbacks, lying about hours worked, and stealing from the company; (3) political deviance (minor-interpersonal), which defines the behaviour as engaging in social interaction that puts other individuals at a personal or political disadvantage. Showing favouritism, gossiping about co-workers, blaming co-workers, and competing nonbeneficially are some of the deviant behaviours that fall within this category: and (4) personal aggression (serious-interpersonal), which refers to acts that are committed in an aggressive or hostile manner toward other individuals. Deviant behaviours in this category include sexual harassment, verbal abuse, stealing from co-workers, and endangering coworkers.

In an attempt to understand why employees engage in deviant acts at the workplace, various scholars have adopted different theoretical frameworks. Based on these theories, previous studies have developed different models using different sets of individual and organisational and situational antecedents to explain the structures involved in organisational misbehaviour. For example, Spector (1997) developed a model of organisational frustration predicated on frustration-aggression theory (Dollard, Doob, Miller, Mowrer, \& Sears, 1939). In this model, he suggested that certain triggering events in the organisation determine the extent of frustration experienced by the employees, which in turn affects the way they behave. O'Learry-Kelly, Griffin, \& Gle'w (1996) identified a number of individual and situational antecedents of organisational aggression using social learning theory (Bandura, 1977). One of the more consistent theoretical underpinnings used to understand organisational misbehaviour is the principle of justice or equity theory (Adams, 1963 \& Greenberg, 1990). In essence, this theory asserts that attitudinal and behavioural outcomes of individuals in the organisation are influenced by the extent to which they perceive whether organisations are just and fair in their practices and procedures. Using this perspective to develop models of organisational misbehaviour in which antecedents were identified, Greenberg (1990), and Skarlicki \& Folger (1997) were able to demonstrate the validity of using this theory to understand employee theft at the workplace and organisational retaliatory behaviours, respectively.

Based on these scattered evidences, Robinson \& Bennett (1997) developed a model of workplace deviance. They argued that some type of provocations typically precede misbehaviour. They posit that financial economic pressures, social pressures, poor working conditions, inequity or unjust treatment, and changes in the work environment (to name a few) are perceived as provocations insofar as these provocations motivate the organisational member to either vent her/his anger and/or make changes in the workplace. Engaging in misbehaviour can fulfil both these goals. For example, they can vent their anger and frustration by targeting the behaviour to the source of provocation. But they further hypothesise that provocations will not necessarily lead to misbehaviour; however, because the organisational member is usually constrained from engaging in misbehaviour, and thus, he/she 
engages in only legitimate actions. Only when he/she perceives that he/she is relatively free from constraints misbehaviour will be exhibited especially if it is the most effective way of achieving the employees' goals (i.e. make changes). Thus, this model assumes that misbehaviour is a motive-based or a goal-directed activity, and that whether or not certain factors in the working environment provoke or trigger misbehaviour is a matter of perception of the individual person. But the authors recognise that the workers do not necessarily engage in rational, conscious decision making in terms of what types of behavioural actions will be chosen which can provide them with the most effective satisfaction. From the management perspective, this validity of the model in providing sufficient explanations of workplace deviance is yet to be empirically tested.

Although various scholars use different theoretical models to explain workplace deviance, these models, apparently, suggest one important implication. They imply that the relationship between workers and management are based on exchange. The main element in any exchange relationship is the notion of reciprocity (Gouldner, 1960), which strongly implies that some form of exchanges between, at least, two main parties to the relationship is effected. According to Gouldner (1960), there are two kinds of reciprocity - positive and negative. While the former concerns returns of benefits, the latter is about returns of injuries. It is the second form of reciprocity that is more relevant to the present study. The idea that negative reciprocity can occur in an employer-employee relationship is advanced by Kemper (1966: 293), who stated that, "when the organisation either as an entity; or in the person of a superior, has defaulted on the obligation of the organisation to its members, reciprocal deviance can result."

He went to say that if this happens, then reciprocal deviance by employees is the deviance evoked as punishment. It is with this general proposition that exchange theory is developed. In this context, deviance theoretically can be interpreted as a form of response toward the exchange that happens.

\section{METHOD}

\section{Data Collection}

To address the above research questions, an exploratory survey was conducted between the month of February and March 2002. Six hotel establishments of varying sizes in Langkawi, which were conveniently selected, voluntarily participated in the survey. Consistent with the research issues addressed earlier, questionnaires were distributed to each of these organisations only to frontline hotel employees, defined as those employees who interact daily with hotel guests in the course of the performance of their work. This definition was consistent with that given by previous authors who investigated front-line hotel employees (Guerrier, 1999; Guerrier \& Adib, 2000). Some other authors used the term "interactive service workers" to refer to the same group of employees (Leidner, 1993). To further validate the definition of the frontline employees, the opinions of the management of each hotel were also sought. In general, their views of who were regarded as frontline employees were consistent with the definition of this study. Consequently, three main groups of workers were identified. They were generally located in three main departments, i.e. the front office department, the housekeeping department, and the food and beverage department. In some hotels, the frontline employees were also located in yet another department, i.e. the recreation department.

The distribution of questionnaires was administered by human resource managers. In order to encourage the employees to answer the questionnaires, they were not asked to provide any personal details in the questionnaires. The anonymity of the responses were vital in this study for it dealt with a topic that was sensitive in nature (Babbie, 1990).

\section{Measures}

Workplace deviance. In order to measure workplace deviance, an instrument developed by Bennett \& Robinson (2000), called the Workplace Deviance Questionnaire was used. According to these authors, deviance at the workplace can be generally grouped into two main categories: in- 
terpersonal and organisation type deviance. The interpersonal deviance refers to acts that are targeted at members of the organisation, and includes acts such as "making fun at someone" and "saying hurtful things to someone." On the other hand, organisational deviance refers to acts that are targeted at the organisation. An example of this type of deviance is "coming in late for work."

To measure the deviance variable, respondents were to indicate whether they have any knowledge of their co-workers performing any of the listed behaviours at the workplace, using a yesno scale.

Work-related attitudes. To tap this variable, the respondents were asked a number of questions about main aspects of work such as the job itself, the reward, the co-workers, the supervision, and the management. These questions were taken from a previous study that attempted to investigate the working lives of the catering industry (Gabriel, 1988). A categorical scale was also used.

Guest behaviour: To tap this variable, a yes-no question was asked. Respondents were asked to indicate whether they had ever encountered any rude or difficult guests while at work.

Demographic questions. Personal data of the respondents were also solicited. They were to indicate their sex, race, religion, marital status, level of education, and age group. These questions were also categorically scaled.

\section{Sample}

Out of 650 questionnaires that were distributed to the hotel workers, only 308 were finally usable for data analysis, representing a valid response rate of 47.4 percent. According to Babbie (1990), a response rate of fifty percent is usually considered adequate in a survey research. Taking this as a guideline, this study's response rate can be considered satisfactory. Due to such a response rate, the study does not claim that its findings are uncontaminated by non-response bias. Indeed, this is one of the inevitable limitations whenever questionnaires are used.
In this survey, the sample came from four main front departments - the housekeeping, the food and beverage, the front office, and other departments such as recreation, as highlighted in Table 1.0. Slightly more female than male employees participated in this survey and, in general, they were of Malay origin. They were relatively young with the majority between the age group of 19 and 40 . Slightly more than fifty percent were already married, either with or without children. The majority of the employees who participated in the survey had low education, with almost half claiming that they managed to complete their SPM. Most of the employees indicated that they were Langkawians, whose families have lived on the: island for generations, while the rest came from other parts of the peninsula, notably from the northern region of Malaysia, such as Perlis, Kedah, and Penang. In general, the personal background characteristics of the sample appeared to be similar with respect to age, gender, education and race to those reported by a study conducted by the Malaysian Tourism Promotion Board in 1994 among local tourism-related establishments such as hotels, travel and tour agencies and airline companies.

\section{RESULTS}

In this section, two main results will be presented. The first one intends to provide some descriptive statistics, i.e. percentages, on the variables involved in the present study. The second one presents sorne inferential statistics to test a number of hypotheses, though not formally formulated, in relation to the second research question.

\section{Descriptive Results}

Types and Forms of Workplace Deviance

As shown in Table 2.0, the respondents in general acknowledged the existence of deviance in the hotel, as had been expected. The table indicates that among the highest responses on deviance, it is apparent that interpersonal deviance, i.e. "saying hurtful things to someone" was found to be the most common form of deviance, as 66.0 
Table 1.0

Demographic Profile of Respondents

\begin{tabular}{|c|c|c|}
\hline Characteristics & $\mathrm{N}$ & Percentages $(\%)$ \\
\hline \multicolumn{3}{|l|}{ Department $(\mathrm{n}=305)$} \\
\hline Housekeeping & 105 & 34.4 \\
\hline Food and beverage & 100 & 32.8 \\
\hline Front office & 56 & 18.4 \\
\hline Others & 44 & 14.4 \\
\hline \multicolumn{3}{|l|}{$\operatorname{Sex}(n=308)$} \\
\hline Male & 151 & 49.0 \\
\hline Female & 157 & 51.0 \\
\hline \multicolumn{3}{|l|}{ Race $(n=305)$} \\
\hline Malay & 252 & 82.6 \\
\hline Chinese & 8 & 2.6 \\
\hline Indians & 6 & 2.0 \\
\hline Others & 39 & 12.8 \\
\hline \multicolumn{3}{|l|}{ Age $(n=302)$} \\
\hline Less than 19 & 8 & 2.6 \\
\hline $19-25$ & 133 & 44.0 \\
\hline $26-32$ & 93 & 30.8 \\
\hline $33-40$ & 56 & 18.5 \\
\hline $41-45$ & 7 & 2.3 \\
\hline $46-50$ & 4 & 1.3 \\
\hline More than 50 & 1 & 0.3 \\
\hline \multicolumn{3}{|l|}{ Marital status $(n=303)$} \\
\hline Single & 131 & 43.2 \\
\hline Married & 160 & 52.8 \\
\hline Divorced/widowed & 12 & 4.0 \\
\hline \multicolumn{3}{|c|}{ Highest level of education $(n=302)$} \\
\hline Primary school & 29 & 9.6 \\
\hline SRP & 52 & 17.2 \\
\hline SPM & 147 & 48.7 \\
\hline STPM/Diploma & 48 & 15.9 \\
\hline University degree & 12 & 4.0 \\
\hline Others & 14 & 4.6 \\
\hline
\end{tabular}


percent of the respondents acknowledged that they had knowledge of the act being committed at the workplace. This deviant act is followed by "coming in late for work," a form of organisational deviance, as was reported by almost sixty percent of the respondents. The third most common act reported by the respondents is "making fun of someone while at work" where more than half of the respondents indicated their knowledge of the act being committed at work.

Table 2.0

Incident of Workplace Deviance $(\mathrm{n}=306)$

Types of workplace deviance Percentages $(\%)^{2}$

Saying hurtful things to someone (ID)' 66.0

Coming in late to work without permission (OD)

Making fun of someone while at work (ID)

Putting little effort into his/her work (OD)

48.0

Intentionally working slower than s/he could have worked (OD)

Neglecting to follow the boss's instructions (OD)

Cursing someone at work (ID)

Acting rudely toward someone at work (ID)

Littering the work environment (OD)

Taking property from work without permission (OD)

Publicly embarrassing someone at work (ID)

Playing a mean prank on someone at work (ID)

Spending too much time fantasising/daydreaming instead of working (OD)

Using an illegal drug/alcohol on the job (OD)

Making an ethnic, religious, or racial remark at work (ID)

Dragging work in order to get overtime (OD)

Discussing confidential company information with an unauthorised person (OD) 11.8

1 ID is an acronym for interpersonal deviance/deviance, and OD for organisational deviance or deviance, following Robinson and Bennett's (1995) classification.

2 The percentages refer to the those who answered 'yes' to the question of whether they had any knowledge of the deviant acts committed in the workplace. 
In addition to the types of deviance that are listed in Table 2.0, some scholars consider turnover as a form of deviance (Ackroyd \& Thompson, 1999). This is because in an industry that relies more on personal characteristics of the employees (which are much more difficult, if not impossible to train), rather than their skills, the employees who have the desired personal qualities are expected by the management to stay rather than leave the hotel. Leaving the hotel by these employees then imply that deviance has been committed. Taking this into consideration, it is reasonable to consider turnover as a form of deviance, at least as far as this industry is concerned. A frequency analysis was run to determine the number of respondents who indicated whether they ever thought of leaving the hotel. Out of 285 respondents, more than half ( 65.3 percent) responded positively to the question of intention to leave (ITL) i.e. that they wanted to leave the hotel.

The results showed that employees exhibited various deviant acts at the workplace. This piece of information is, hence, able to provide answers to the first research question.

\section{Attitudes toward Work}

Table 3.0 highlights the attitudes the respondents had towards their work. In general, many felt that they were neither strongly satisfied nor dissatisfied with their co-workers and the supervision they received on the job. More than fifty percent felt that their job was interesting. It has been suggested that the hotel industry is notorious for its treatment to its workers that they are often asked to work long hours with small pay (Wood, 1992). This claim is evident based on the responses given by the hotel employees who participated in the survey. Marly expressed dissatisfaction with the pay they received, as indicated in Table 3.0. Two additional aspects of work that many expressed dissatisfaction with were management and job security. For many, managers were perceived to be unfair (71.1 percent) in their dealings with the workers or viewed to be unsupportive ( 80.3 percent) and this led to a stressful experience. In general, working conditions were regarded with suspicion and lack of trust by the employees of the management. Many indicated their adverse feelings and emotions toward the management for various reasons, such as difficulties in attaining job promotions, lack of freedom in solving workrelated problems, rejection of their work-related ideas by the management, lack of involvement and discussion prior to any major changes that affect their work, and fear that they will be easily dismissed when the hotel is not making money.

Table 3.0

Attitudes Toward Each Aspect of the Job

\begin{tabular}{lc}
\hline Aspects of Job & Percentages $(\%)$ \\
\hline & \\
Are you satisfied with the pay and fringe benefits? $(\mathrm{n}=304)$ & 33.6 \\
Yes & 66.4 \\
No & \\
& 51.1 \\
Are you satisfied with the co-workers? $(\mathrm{n}=307)$ & 48.9 \\
Yes & \\
No &
\end{tabular}


(continued)

Aspects of Job

Percentages (\%)

Are you satisfied with the supervision? $(n=305)$

Yes

No

Are you satisfied with job security? $(n=306)$

Yes

No

Is the management fair? $(\mathrm{n}=304)$

Yes

No

Is the management concerned about the employees? $(n=303)$

Yes

Sometimes

55.6

No

How do you perceive your job? $(\mathrm{n}=301)$

Interesting all the time

Most of the times it is interesting

67.4

Most of the times it is dull

14.3

Completely dull

\section{Guests Behaviour}

According to a number of scholars (e.g. Guerrier \& Adib, 2000; Korczynski, 2002), hotel employees do come into contact with rude and difficult guests in the course of their work performance. Similar instances were also observed by respondents in the present study. However, only a small percentage of respondents $(18.2 \%)$ indicated that they had ever encountered rude and difficult guests at work. The majority of them reported otherwise, i.e. that they had never come across guests who were rude and difficult while at work.

\section{Inferential Results}

\section{Attributes to Deviance}

A second research question to be answered in this study was whether the incident of deviance can be attributed to factors in the workplace as being proposed by the existing theories of work responses. Although not explicitly formulated, it was hypothesised that deviance is influenced by attitudes people have toward the workplace. In the statistical context, the former was labelled as the independent variable and the latter the dependent variable. In order to test the hypotheses to determine whether there was a significant relationship between factors at work and workplace deviance, chi-square analyses were run. This kind of statistical test is appropriate given that categorical scales were used to measure both variables (Sekaran, 2002).

As expected, a number of significant relationships were found between factors at work and workplace deviance. Table 4.0 summarises these findings. As shown in the table, attitudes toward pay, co-workers, supervision, and management 
had significant associations with whether or not frontline hotel employees engage in deviance. For example, pay was significantly correlated with making fun at work $\left(\chi^{2}=15.583, \mathrm{df}=1, \rho=0.0001\right)$, with coming in late to work without permission $\left(\chi^{2}=10.549, \mathrm{df}=1, \rho=0.002\right)$, and with working slower than expected $\left(\chi^{2}=13.114, \mathrm{df}=1\right.$, $\rho=0.0001$ ).

Many have argued that employees quit their place of work as a response to a variety of factors, and one of which is work-related (e.g.
Hirschman, 1970). In order to examine whether there is a correlation between aspects of the job and intent to leave, chi-square analyses was performed. As expected, statistically significant relationships were found between various aspects of the job and intent to leave, for example, between pay and $\operatorname{ITL}\left(\chi^{2}=21.704, \mathrm{df}=1, \rho=0.0001\right)$, and between management fairness and ITL $\left(\chi^{2}=28.808, \mathrm{df}=1, \rho=0.0001\right)$. This can also be seen in Table 4.0 .

Table 4.0

Chi-Square Results of Work-Related Attitudes and Workplace Deviance (2-tailed-tests)'

\begin{tabular}{|c|c|c|c|c|c|c|c|}
\hline & \multicolumn{7}{|c|}{ Work-related attitudes ${ }^{2}$} \\
\hline & Pay & $\begin{array}{c}\text { Co- } \\
\text { workers }\end{array}$ & Supervision ${ }^{3}$ & $\begin{array}{c}\text { Job } \\
\text { security }\end{array}$ & $\begin{array}{l}\text { Management } \\
\text { Fairness }^{3}\end{array}$ & $\begin{array}{l}\text { Workers' } \\
\text { Welfare }^{4}\end{array}$ & $\begin{array}{c}\text { Perception } \\
\text { of Job }^{5}\end{array}$ \\
\hline Deviance & & & & & & & \\
\hline Making fun & $\begin{array}{c}15.583^{6} \\
(0.0001)^{7}\end{array}$ & $\begin{array}{c}18.493 \\
(0.0001)\end{array}$ & $\begin{array}{c}14.176 \\
(0.0001)\end{array}$ & Ns & $\begin{array}{c}6.390 \\
(0.011)\end{array}$ & Ns & Ns \\
\hline $\begin{array}{l}\text { Saying hurtful } \\
\text { things }\end{array}$ & $\mathrm{Ns}^{\kappa}$ & $\begin{array}{c}26.021 \\
(0.0001)\end{array}$ & $\begin{array}{c}7.879 \\
(0.007)\end{array}$ & Ns & Ns & Ns & Ns \\
\hline $\begin{array}{l}\text { Making } \\
\text { remarks }\end{array}$ & Ns & $\begin{array}{c}21.023 \\
(0.0001)\end{array}$ & Ns & Ns & Ns & $\begin{array}{c}9.982 \\
(0.007)\end{array}$ & Ns \\
\hline $\begin{array}{l}\text { Cursing } \\
\text { someone }\end{array}$ & $\begin{array}{c}7.925 \\
(0.005)\end{array}$ & $\begin{array}{c}32.036 \\
(0.0001)\end{array}$ & $\begin{array}{c}9.451 \\
(0.002)\end{array}$ & Ns & $\begin{array}{c}5.495 \\
(0.022)\end{array}$ & $\begin{array}{c}9.089 \\
(0.011)\end{array}$ & Ns \\
\hline $\begin{array}{l}\text { Playing a } \\
\text { mean prank }\end{array}$ & $\begin{array}{c}11.943 \\
(0.001)\end{array}$ & $\begin{array}{c}25.823 \\
(0.0001)\end{array}$ & $\begin{array}{c}23.935 \\
(0.0001)\end{array}$ & Ns & Ns & $\begin{array}{c}6.527 \\
(0.038)\end{array}$ & Ns \\
\hline Acting rudely & Ns & 31.009 & $\begin{array}{c}14.742 \\
(0.0001)\end{array}$ & $\begin{array}{c}\text { Ns } \\
(0.0001)\end{array}$ & $\begin{array}{c}6.282 \\
(0.016)\end{array}$ & $\begin{array}{c}16.306 \\
(0.0001)\end{array}$ & Ns \\
\hline $\begin{array}{l}\text { Embarrassing } \\
\text { someone }\end{array}$ & Ns & $\begin{array}{c}30.205 \\
(0.0001)\end{array}$ & $\begin{array}{c}18.329 \\
(0.0001)\end{array}$ & Ns & $\begin{array}{c}12.622 \\
(0.0001)\end{array}$ & $\begin{array}{c}13.624 \\
(0.001)\end{array}$ & Ns \\
\hline Taking property & Ns & $\begin{array}{c}14.697 \\
(0.0001)\end{array}$ & $\begin{array}{c}8.303 \\
(0.004)\end{array}$ & Ns & Ns & $\begin{array}{l}12.610 \\
(0.002)\end{array}$ & Ns \\
\hline Fantasising & $\begin{array}{c}7.695 \\
(0.007)\end{array}$ & $\begin{array}{c}22.710 \\
(0.0001)\end{array}$ & $\begin{array}{c}5.983 \\
(0.021)\end{array}$ & $\begin{array}{l}4.478 \\
(0.04)\end{array}$ & $\begin{array}{c}5.691 \\
(0.018)\end{array}$ & $\begin{array}{c}7.652 \\
(0.022)\end{array}$ & Ns \\
\hline
\end{tabular}




\begin{tabular}{|c|c|c|c|c|c|c|c|}
\hline & \multicolumn{7}{|c|}{ Work-related attitudes ? } \\
\hline & Pay $^{3}$ & $\begin{array}{c}\text { Co- } \\
\text { workers }\end{array}$ & Supervision $^{3}$ & $\begin{array}{c}\text { Job } \\
\text { security }^{3}\end{array}$ & $\begin{array}{l}\text { Management } \\
\text { Fairness }^{3}\end{array}$ & $\begin{array}{l}\text { Workers' } \\
\text { Welfare }^{4}\end{array}$ & $\begin{array}{c}\text { Perception } \\
\text { of Job }\end{array}$ \\
\hline Coming in late & $\begin{array}{r}10.549 \\
(0.002)\end{array}$ & $\begin{array}{c}17.903 \\
(0.0001)\end{array}$ & $\begin{array}{c}5.081 \\
(0.025)\end{array}$ & Ns & $\begin{array}{c}4.209 \\
(0.051)\end{array}$ & $\begin{array}{c}22.046 \\
(0.0001)\end{array}$ & Ns \\
\hline $\begin{array}{l}\text { Littering work } \\
\text { environment }\end{array}$ & $\begin{array}{c}5.150 \\
(0.028)\end{array}$ & $\begin{array}{c}8.778 \\
(0.003)\end{array}$ & Ns & $\begin{array}{c}3.913 \\
(0.049)\end{array}$ & Ns & Ns & Ns \\
\hline $\begin{array}{l}\text { Disobeyed } \\
\text { instructions }\end{array}$ & $\begin{array}{c}5.060 \\
(0.028)\end{array}$ & $\begin{array}{c}27.261 \\
(0.0001)\end{array}$ & $\begin{array}{c}13.628 \\
(0.0001)\end{array}$ & $\begin{array}{c}4.348 \\
(0.046)\end{array}$ & $\begin{array}{c}16.131 \\
(0.0001)\end{array}$ & $\begin{array}{r}10.479 \\
(0.005)\end{array}$ & $\begin{array}{c}8.846 \\
(0.031)\end{array}$ \\
\hline Working slower & $\begin{array}{c}13.114 \\
(0.0001)\end{array}$ & $\begin{array}{c}34.882 \\
(0.0001)\end{array}$ & $\begin{array}{l}10.935 \\
(0.001)\end{array}$ & $\begin{array}{c}4.169 \\
(0.047)\end{array}$ & $\begin{array}{l}10.776 \\
(0.001)\end{array}$ & $\begin{array}{c}7.764 \\
(0.021)\end{array}$ & $\begin{array}{l}11.428 \\
(0.01)\end{array}$ \\
\hline $\begin{array}{l}\text { Discussing } \\
\text { information }\end{array}$ & Ns & $\begin{array}{c}8.922 \\
(0.004)\end{array}$ & $\begin{array}{l}9.140 \\
(0.004)\end{array}$ & Ns & Ns & $\begin{array}{l}9.142 \\
(0.01)\end{array}$ & Ns \\
\hline $\begin{array}{l}\text { Using drug } \\
\text { alcohol }\end{array}$ & Ns & Ns & $\begin{array}{c}8.403 \\
(0.004)\end{array}$ & Ns & Ns & Ns & Ns \\
\hline $\begin{array}{l}\text { Putting little } \\
\text { effort }\end{array}$ & $\begin{array}{c}13.097 \\
(0.0001)\end{array}$ & $\begin{array}{c}27.016 \\
(0.0001)\end{array}$ & $\begin{array}{l}11.127 \\
(0.001)\end{array}$ & $\begin{array}{c}6.063 \\
(0.015)\end{array}$ & $\begin{array}{c}5.306 \\
(0.023)\end{array}$ & $\begin{array}{l}15.140 \\
(0.001)\end{array}$ & Ns \\
\hline Dragging work & Ns & $\begin{array}{c}17.052 \\
(0.0001)\end{array}$ & $\begin{array}{c}7.520 \\
(0.007)\end{array}$ & Ns & Ns & $\begin{array}{c}5.881 \\
(0.053)\end{array}$ & Ns \\
\hline $\begin{array}{l}\text { Intending to } \\
\text { leave }\end{array}$ & $\begin{array}{c}21.704 \\
(0.0001)\end{array}$ & $\begin{array}{c}19.662 \\
(0.0001)\end{array}$ & $\begin{array}{c}16.438 \\
(0.0001)\end{array}$ & $\begin{array}{l}31.146 \\
(0.0001)\end{array}$ & $\begin{array}{c}28.808 \\
(0.0001)\end{array}$ & $\begin{array}{c}24.270 \\
(0.0001)\end{array}$ & $\begin{array}{c}6.583 \\
(0.0037)\end{array}$ \\
\hline
\end{tabular}

Only significant results are shown, where p 0.05 .

All of the work-related attitudes correspond to those listed in Table 3.0

Degrees of freedom $=1$

Degrees of freedom $=2$

Degrees of freedom $=3$

Figures refer to $\chi^{2}$

Numbers in parentheses refer to the significance level

8 Not significant

In the hotel industry, a triangular working relationship exists among the main players, i.e. among the workers, the management, and the hotel customers. In this relationship, employees' responses can be attributed directly to the management and shaped by the behaviour of the guests. In this study, it was hypothesised that relationships with guests would have some bearing on how employees would respond, which could be in the form of organisational deviance. Chi-square analyses were performed and the results are shown in Table 5.0. The results indicated that significant associations existed between encountering rude guests and coming in late $\left(\chi^{2}=6.929, \mathrm{df}=1\right.$, $\rho=0.01$ ), and taking hotel's property without permission $\left(\chi^{2}=7.745, \mathrm{df}=1, \rho=0.006\right)$. 
Table 5.0

Chi-Square Results of Guests' Behaviour and Workplace Deviance (2-tailed tests) a

\section{Guests' Behaviour $^{\mathrm{b}}$}

Deviance:

Making fun

Ns

Saying hurtful things

$5.105^{c}$

$(0.028)^{\mathrm{d}}$

Making remarks

$\mathrm{Ns}^{\mathrm{e}}$

Cursing someone

4.301

(0.052)

Playing a mean prank

Ns

Acting rudely

Ns

Embarrassing someone

Ns

Taking property

7.745

$(0.006)$

Fantasising

Ns

Coming in late

6.929

(0.01)

$\begin{array}{lll}\text { Littering work environment } & \text { Ns }\end{array}$

Disobeying instructions $\quad$ Ns

Working slower $\quad$ Ns

Discussing information Ns

Using drug/alcohol Ns

$\begin{array}{lll}\text { Putting little effort Ns } & \text { No }\end{array}$

Dragging work Ns

Intending to leave

a Only significant results are shown, where p 0.05 .

b Degrees of freedom $=1$

Figures refer to $\chi^{2}$

Numbers in parentheses refer to the significance level

- Not significant 


\section{DISCUSSION}

The main aim of the survey was to investigate the phenomenon of workplace deviance among frontline hotel employees in Langkawi. In its attempt to achieve this objective, two specific research questions were formulated. The first question related to the types of deviance employees engage in at the workplace. The second question was to examine whether factors at work played a significant role in influencing deviance at work. In general, the present study was able to provide answers to the research questions.

With respect to the first question, the present study revealed that employees engage in a number of deviant acts at the workplace. In particular, this study found that three types of deviant acts stand out as more commonly committed by employees at work. They are: saying hurtful things at work, coming to work late, and making fun of someone at work. How did the findings of the present study fare with those found by previous authors? The study conducted by Bennett \& Robinson (2000) was specifically aimed at developing and validating the instrument of workplace deviance. To achieve this, a number of separate studies were consequently carried out. The first study involved 226 respondents, of whom 126 were full-time employees and 100 were MBA students. In the second study, 352 full-time employees with diverse occupations were involved. In both these studies, the respondents were given a list of 24 different types of deviance. They were asked to indicate on a 7-point Likert scale ranging from 1 (never) to 7 (daily) the extent to which they had engaged in each of the behaviours in the previous year. In comparing this the findings of this study with those of Bennett \& Robinson's, it appears that, in general, they are rather consistent. In Bennett \& Robinson's study, the types of deviance that were reported to be engaged in by the respondents at least once a year included, among others, making fun of someone while at work, coming in late without permission, and saying hurtful things to someone.

The findings of the present study depict that the most common forms of deviant acts in the workplace were not "serious" acts of deviants, such as "stealing" (i.e. taking property without permission), discussing confidential information, or making ethnic, racial or religious remarks. Due to the less "serious" forms of acts reported in this study, one wonders whether the responses are reflective of the "true" scenario of deviance in Malaysia. While the "truth" will never be known, there is no reason to question the validity of responses given by the respondents. Firstly, cultural and normative values might inform the less "serious" forms of deviant act reported in this study. In the context of this study, the majority of the respondents are Malay Muslims. As Muslims, they are expected to uphold certain religious practices and are prohibited to engage in a number of wrongful (i.e. deviant) acts. For example, in Islam, one is prohibited to consume alcohol. As the prohibition of consuming alcohol is universal, it is expected that, the act of consuming alcohol while at work will generate low responses, as can be seen in Table 2.0. Making an ethnic, religious, or racial remark at work was another act that received low responses. The fact that few of the respondents were non-Malays (a scenario which is also true of front-line hotel employees in Langkawi), it is reasonable to expect that this act scored relatively low. Furthermore, because Malaysia comprises people of different ethnics and religions, the development and maintenance of racial and religious harmony is always an important social cliscourse.

In addition to cultural practices, the interviews with the human resource managers in the participating hotels have also helped in affirming of the results. In these interviews, they were asked whether there were "behavioural problems" among their employees in their establishments and if yes what would they be. They affirmed that staff employees did engage in deviant acts, which included acts of disobedience, coming to work late, smoking, etc. Thus, the information provided by the managers corresponded to the managers' reports on the types of misconduct they were aware of formally. Furthermore, as various precautions were taken in designing and implementing the survey, there was no reason to argue that the answers were not reflective of the respondents' experiences in the hotel. 
With respect to the second research question of what perceived work-related factors accounted for the exhibition of workplace deviance, the findings of the present study was also able to shed some light. In general, the findings suggested that perceived aspects of the job, which include pay, supervision, co-workers, and management were significantly related to workplace deviance. Although chi-square tests are tests of association, causation certainly cannot be implied from the results. However, since the formulation of the study's hypotheses was determined based on some prior theoretical foundation or framework, it was reasonable to suggest that factors at work did have some influence or affect or have some bearing on the (miss) behaviour of employees, in general. Thus, based on this, it was possible to suggest that the more favourable the aspects of job perceived by employees, the less likely that they will engage in workplace deviance. In view of these findings, this study has provided a significant piece of evidence that frontline hotel employees, when faced with the above situation, will engage in deviance. Such finding appeared to be consistent with previous studies that investigated the same phenomenon of deviance (e.g. Bennett \& Robinson, 2000). In a study conducted by Vardi (2001) to determine the effects of organisational climate on misconduct at work among $150 \mathrm{em}-$ ployees from various departments of a metal-product company in northern Israel, he found that there was a significant negative relationship between the two variables.

Extrapolating the exchange framework to the findings, it can be suggested that people commit deviance for a reason, i.e. to retaliate or get even with the perpetrator. So when employees engage in deviance, they do so to seek retribution against the organisation because they perceive that they are being mistreated. That is, when they view that the organisation has defaulted in their psychological contract (Turnley \& Feldman, 1999a, 1999 b), they are likely to respond in such a way that the organisation will "feel" the pain of mistreating them. Thus, in the case of significant association between satisfaction with pay and coming in late found in the present study, it can be said that when employees feel that they are not being satisfactorily treated by the organisation they will be more likely to come in late to work without permission. Theoretically, by coming in late to work, the employees are directly targeting their act at the organisation perceived to have been dishonouring the psychological contract that has been established. According to Robinson \& Bennett (1995), when the employees do so, the well-being of the organisation is threatened and or harmed.

According to the exchange framework, by engaging in retaliatory acts (Skarlicki. Folger, \& Tesluk, 1998) the perpetrators hope to see or make some changes within the organisation. In this study, as significant associations exist for example. between satisfaction with pay and deviance, the theoretical framework, propounds that employees misbehave to signal to the organisation their resentment, which hopefully will be addressed by the organisation. In this case, the resentment is about dissatisfaction with the pay the organisation offers. A sirnilar argument can also be applied to forms of interpersonal deviance, as in the case of significant associations that appear to exist between satisfaction of co-workers and making fun of someone at work, for instance. Theoretically speaking, it is reasonable to expect that satisfaction with co-workers will be related to interpersonal form of deviance only and not with organisational form of deviance because satisfaction with co-workers involves and implies some degree of interpersonal relationships and communications. The result suggests that the less satisfied the employees are toward their co-workers, the more likely they are to engage in deviance. Thus, in the case of saying hurtful things, when the employees are not satisfied with the way their co-workers perform their work or with any other aspects of the relationship, then the employees are more likely to say hurtful things to their co-workers as a way to voice their dissent or resentment.

As indicated earlier, employee deviance is also shaped and influenced by their interaction and contact with the hotel guests. It has been argued that by virtue of the nature of the interactive service work, customers play an important role as the source of satisfaction (or pain/displeasure) for the workers. Through the hiring and recruitment of the front-line employees which tends to generally favour those who have certain desired 
qualities (Jones, Taylor, \& Nickson 1997), and through their socialisation into holding strong customer attitudes, particularly customer empathy (Korczynski, 2002), rude and irate hotel guests are likely to cause considerable pain to the workers. "When a party to whom you are empathetic and favourably disposed to turns against you in an irate manner this is likely to cause sharp pain" (Korczynski, 2002: 76). This is because the workers and the customers are in a socially embedded relationship, rather than in a purely transactional one. "When two people undertake an economic exchange they are also necessarily taking part in a social relationship - a social relationship which can have meaning or displeasure quite distinct from the economic exchange taking place" (Korczynski, 2002: 75). Thus, the rude or difficult customers are likely to display possible theoretical responses, one of which being in the form of deviance as the behaviours of the customers might be perceived as a source of displeasure for their work. By coming in to work late, for example, the workers might use this act as an escape mechanism.

It should be noted that there are a number of research caveats that should be taken into consideration when interpreting the results of this study. Apart from the issue of causality, the issue of reciprocity is also relevant when interpreting the findings. It is also possible that reciprocal relationships exist between the two variables in that instead of aspects of the job influencing deviance, the reverse can also be true as well. Deviance can also shape the attitudes that people have toward their work. It is likely that people who are "truant" have unfavourable attitudes toward the workplace. However, as stated by Littler (1982: 26-27; as cited in Ackroyd \& Thompson, 1999), when people come in to work, they do not come with opposing attitudes toward the work system. Rather, attitudes toward work normally develop after they have been socialised into the system. Thus, based on this argument it is more realistic to interpret deviance as a response rather than an antecedent of attitudes at the workplace. The last caveat that needs to be taken into account is whether the findings could be generalised to a wider population of employees given that nonrandom sampling is involved. Whilst this is true, the generalisation of the findings is not particularly questioned. This is because, as pointed out by many scholars (e.g. Wood, 1992), hotels appear to have similar characteristics, especially in terms of their human resources.

From the practical point of view, this study may have important practical implications for managers and practitioners. In order to manage and control workplace deviance, it is important for managers to examine their management practices and policies at work. By ensuring that working conditions are perceived to be conducive and fair, management can benefit by having conforming and obedient employees at work. As frontline hotel employees have to deal directly with guests in the course of performing their work, it is important for them not to engage in deviant acts as a way to respond to difficult and rude guests. If the management wishes to maintain the arrivals of hotel guests to their hotel, then it is necessary for the management to provide sufficient guest-related training and stress management techniques to their workers. Such training is beneficial and valuable in the long run in attracting more tourists Langkawi and other parts of the country as well.

This study has also been able to contribute to the theoretical and research development in the area of workplace deviance. More research needs to be carried out to further understand this phenomenon at the workplace. Since this study was particularly conducted among hotel employees, studies on employees of different kinds of organisations in Malaysia should be carried out. Due to the non-serious nature of workplace deviance found in this study, more research efforts should also be taken to determine the causes of serious deviant acts at the workplace. Other factors at work should also be examined, such as training and development. It is theoretically possible to hypothesise that employees' engagement in deviance is also prompted by the lack of training they receive at work, for example, in the case of stealing or discussing confidential information. If such is the case, the reason for engaging in deviance acts at the workplace should, therefore, not be confined solely to venting to anger or frustration on the management but rather to providing employees with sufficient training in the first place with respect to the do's and dont's at work. 


\section{REFERENCES}

Ackroyd, S. \& Thompson, P. (1999). Organisational misbehaviour. London: Thousand Oaks.

Adams, J. (1963). Toward an understanding of inequity. Journal of Abnormal and Social Psychology, 67, 422-436.

Babbie, E. R. (1990). Survev research methods. Belmont, California: Wadsworth Publishing Company, Inc.

Bandura, A. (1977). Social learning theory. Englewood Cliffs, NJ: Prentice Hall.

Bennett, R. J. \& Robinson, S. L. (2000). Development of a measure of workplace deviance. Journal of Applied Psychology, 85 (3), 349360.

Burawoy, M. (1979). Manufacturing consent: Changes in the labour process under monopoly capitalism. Chicago: Chicago University Press.

Dollard, J., Doob, L. W., Miller, N. E., Mowrer, O. H. \& Sears, R. R. (1939). Frustration and aggression. New Haven: Yale University Press.

Gabriel, Y. (1988). Working lives in catering. London: Routledge \& Kegan Paul.

Giacalone, R. A., \& Greenberg, J. (1997). Antisocial behaviour in organisations. Thousand Oaks: Sage Publications.

Gouldner, A.W. (1954). Patterns of industrial bureaucracy. New York: The Free Press.

Gouldner, A. W. (1960). The norm of reciprocity: A preliminary statement. American Sociological Review, 25(2), 161-178.

Greenberg, J. (1990). Employee theft as a reaction to underpayment inequity: The hidden cost of pay cuts. Journal of Applied Psychology, 75, 561-568.

Griffin, R. W., O'Leary-Kelly, A. \& Collins, J. (1998). Dysfunctional work behaviours in organisations. In C. L. Cooper \& D. M. Rousseau (Eds), Trends in Organisational Behaviour, 5 (pp. 65-82). Chichester: John Wiley \& Sons Ltd.

Guerrier, Y. \& Adib, A. S. (2000). 'No, we don't provide that service': The harassment of hotel employees by customers. Work, Employment and Society, 14 (4), 689-705.

Guerrier, Y. (1999). Organisational behaviour in hotels and restaurants: An international perspective. Chichester: John Wiley \& Sons Ltd.

Halim, Fatimah. (1983). Workers' resistance and management control: A comparative case study of male and defame workers in West Malaysia. Journal of Contemporary Asia, 13 (2), 131-150.

Jones, C., Taylor, G. \& Nickson, D. (1997). Whatever it takes? Managing 'empowered' employees and the service encounter in an international hotel chain. Work, Employment and Society, 11 (3), 541-554.

Kemper, T. D. (1966). Representative roles and the legitimation of deviance. Social Problems, 13, 288-298.

Korczynski. M. (2002). Human resource management in service work. Basingstoke: Palgrave.

Leidner, R. (1993). Fast food, fast talk: Service work and the routinisation of everyday life. Berkeley: University of California Press.

Levidow, L. (1991). Women who make the chips. Science as culture, 2, 103-124.

McCammon, H. J. \& Griffin, L. R. (2000). Workers and their customers and clients: An editorial introduction. Work and Occupation, 27 (3), 278-293. 
Malaysian Tourism Promotion Board (1994). Tourism manpower survey 1994. Kuala Lumpur: Unit Statistik, Bahagian Penyelidikan, Lembaga Penggalakan Pelancongan Malaysia.

Ong. A. (1987). Spirits of resistance and capitalist discipline: Factory women in Malaysia. Albany, NY: State University of New York Press.

Piso, A. (1999). Hotel and catering workers: Class and unionisation. Emplovee Relations, 21 (2), 176-188.

Robinson, S. L. \& Bennett, R. J. (1995). A typology of deviant workplace behaviours: A multidimensional scaling study. Academy of Management Journal, 38 (2), 555-572.

Robinson, S. L. \& Bennett, R. J. (1997). Workplace deviance: Its definition, its manifestations, and its causes. In R. J. Lewicki, R. J. Bies, \& B. H. Sheppard (Eds.), Research on Negotiation in Organisations (6) 3-28. Jai Press.

Roy, D. (1952). Quota restriction and goldbricking in a machine shop. American Journal of Sociology, .57 (5), 427-442.

Sekaran, U. (2002). Research methods for business. New York: John Wiley and Sons.

Shamir, B. (1980). Between service and servility: Role conflict in subordinate service roles. Human Relations, 33 (10), 741-756.

Shamir, B. (1981). The workplace as a community: The case of British hotels. Industrial Relations, 12, 45-56.Sayer, A. (2000). Real- ism and social science. London: Sage Publications.

Skarlicki, D. P., Folger, R. \& Tesluk, P. (1998). Personality as a moderator in the relationship between fairness and retaliation. Academy of Management Journal, 42 (1), 100-108.

Sosteric, M. (1996). Subjectivity and the labour process: A case study in the restaurant industry. Work, Employment and Society, 10 (2), 297-318.

Skarlicki, D. P. \& Folger, R. (1997). Retaliation in the workplace: The rules of distributive, procedural, and interactional justice. Journal of Applied Psychology, 82, 416-425.

Spector, P. E. (1978). Organisational frustration: A model and review of the literature. Journal of Applied Psychology, 31, 815-829.

Turnley, W. H. \& Feldman, D. C. (1999a). A discrepancy model of psychological contract violations. Human Resource Management Review, 9 (3), 367-386.

Turnley, W. H. \& Feldman, D. C. (1999b). The impact of psychological contract violations on exit, voice, loyalty, and neglect. Human Relations, 52 (7), 895-922.

Vardi, Y. (2001). The effects of organisational and ethical climates on misconduct at work. Journal of Business Ethics, 29, 325-337.

Vardi, Y., \& Wiener, Y. (1996). Misbehaviour in organisations: A motivational framework. Organisation Science, 7 (2), 151-165.

Wood, R. C. (1992). Working in hotels and catering. London: Routledge. 